\title{
Accountability, Democracy and Post-growth: Civil Society Rethinking Political Economy and Finance
}

\author{
LORENZO FIORAMONTI* \& EKKEHARD THÜMLER** \\ * Centre for the Study of Governance Innovation, Department of Political Sciences, University of Pretoria, \\ South Africa \\ ** Centre for Social Investment, Heidelberg University, Heidelberg, Germany \\ Correspondence Address: \\ Lorenzo Fioramonti, Centre for the Study of Governance Innovation, Department of Political Sciences, \\ University of Pretoria, 0002 Pretoria, South Africa. Email: lorenzo.fioramonti@up.ac.za;
}

\begin{abstract}
Since the fall of the investment bank Lehman Brothers, the economic downturn has taken a heavy toll on many countries. In the public and academic discourse on necessary remedies and reforms, the spotlight is on the role of political elites and business. The actual and potential role of civil society is hardly mentioned in these debates. Yet, it is within civil society that an alternative paradigm and fundamental rethinking of conventional wisdom may emerge. In this volume we present three different ways to frame the crisis and explore the corresponding roles of civil society actors: reinforcing public accountability, regaining democracy and exploring post-growth scenarios. Our goal is to investigate the potentially transformative role of civil society in order to reflect on possible paths towards social change that are not merely remedial but also (re-)constructive in nature.
\end{abstract}

KEY WORDS: Economic crisis, financial markets, civil society, social change, philanthropy, accountability, democracy, de-growth

\section{The Global Financial Crisis: Causes and Impacts}

After a temporary relief, the global financial crisis is back full steam. Over four years since the fall of the investment bank Lehman Brothers, which soon became the iconic representation of Wall Street's misconduct, the economic downturn has taken a heavy toll on many countries, especially in Europe and North America. Not only has the 'double dip' led to a meltdown of private investments and public welfare; worse, for society at large, the global crisis has become a serious threat to the tenability of sovereign democratic states. More than ever, governments are under attack from financial speculation and increasing pressure to introduce policies of austerity and enhance competitiveness by means of reducing wages and increasing the flexibility of the labour market - in other words, to sustain the very neo-liberal policies of the last decades that are allegedly the only rational option available, an argument that has come to be know under the name of TINA ('there is no alternative'). While the longterm consequences of these developments are hard to predict, governmental responses point to a general downsizing of the public sector that is resulting in retrenchments and cuts in the social and welfare systems. In countries like Greece, Portugal, Spain and Italy, these decisions have led to a widespread social and political crisis, affecting individual citizens, political accountability and the stability of society as a whole.

There is a widely shared consensus that the financial downturn originated from the reckless behaviour of commercial banks and financial service providers-private and public alike - exacerbated by the liberalization of financial markets, lack of effective public monitoring, and a generalized herd mentality paving the way for mass investment in rather obscure financial products, further amplified by a crisis of public debts (Stiglitz, 2010; Roubini \& Mihm, 2011). In spite of the turmoil and massive public criticism, though, there is little evidence that international finance has learnt the lesson. In the wake of the crisis, banks and other financial actors have been charged for the manipulation of the LIBOR rate, money 
laundering, complicity in tax evasion, illegal evictions of house owners, assistance in fraudulent $\mathrm{CO} 2$ certificate trafficking, and even colluding at the expense of their own customers (to name but a few). Many banks have resumed their old habits of awarding skyrocketing bonuses to their top management in spite of public outcry, while hedge funds keep operating largely beyond any control. As only very modest reforms have yet been implemented, speculation is likely to be back on track as it was before 2008. Often, it is directed against the very states that saved the financial system from collapse through massive bailouts. Should a new crisis burst in the future, taxpayers most likely will be forced to pay the bill again.

As a consequence of the crisis, public institutions have also come under severe threat. The financial crisis has not only revealed the disastrous impact that failing markets can have on the well-being of contemporary societies. It has also shown that governments actually exercise very little oversight. For the time being, governance seems to work almost the other way round: it is private actors that keep public institutions in check. In the Eurozone, markets have fundamentally dictated political outcomes (like those leading to the establishment of technocratic governments in Greece and Italy) and private companies, such as the credit rating agencies, have acquired the power of ultimate judges of governments' macroeconomic policies, despite these organizations' responsibilities in triggering the global crisis in the first place.

The nonprofit sector has also suffered the consequences of the financial downturn. Public as well as private funding has shrunk, while social tensions are on the rise, thereby placing an additional strain on non-governmental organizations (NGOs), voluntary organizations and other nonprofit entities running on tight budgets. As funding has started plummeting, proposals for a 'bailout' for the nonprofit sector have been voiced in a number of nongovernmental forums across the Atlantic. The Foundation Center, a US-based service provider to philanthropic foundations, has set up a specific programme to focus on the economic crisis in order to support nonprofits through the recession and help them strengthen their fundraising skills. A few other foundations have launched initiatives to help nonprofits adapt to the new financial climate and re-organize their business model in an age of austerity. Yet, a survey focusing on how US philanthropic foundations have been supporting nonprofits during the recession concludes that foundations provide little systemic help in responding to the real challenges of the downturn (Minhas \& Buteau, 2010).

\section{Public Discourse and Civil Society}

In the face of a crisis that has turned into a meltdown of financial markets, public budgets and, by and large, democratic accountability, intellectuals such as Jürgen Habermas (2011), Amartya Sen (2009), Joseph Stiglitz (2012) and Wolfgang Streeck (2012b) have urged the public and the social sciences to look at these events as a fundamental wake-up call: a signal that our conventional political economy and, perhaps, the very foundations of our societies need a serious rethinking. However, when it comes to the question of how to re-contain the financial markets, we see two remarkable shortcomings in public and academic debates. First, the spotlight is almost exclusively on the role of political elites and economic actors (e.g. Lounsbury \& Hirsch 2010; but see Davis 2010 in the same volume). Aside from considerable attention directed towards the Occupy Wall Street movement, the actual (and potential) role of civil society is hardly mentioned in these discussions. Yet, as Antonio Gramsci (1971) famously suggested, civil society is the social sphere where cultural hegemony is won or lost. Hence, it is exactly within civil society that important responses to the crisis may emerge. It is within civil society than an alternative paradigm and a fundamental rethinking of conventional wisdom may be fostered. To be sure, civil society actors do not necessarily play 
a counteracting role vis-à-vis financial powers. Business associations, for instance, may just as well lobby to uphold the status quo (Desai \& Said, 2001; Scholte, essay in this volume). Yet, the following collection of essays explicitly aims to explore those actual and potential contributions of civil society that may be instrumental in tackling the root causes of the current financial and economic crisis. The aim is to gain a broader picture of the kind of problems civil society actors face, and of what their responses and strategies (may) look like.

Second, it is not without irony that the general public as well as policy makers and organizations (like the Institute for New Economic Thinking launched by reborn financier George Soros) preferably turn to economics to seek answers (Munir, 2011) - to the very discipline, that is, that was instrumental in shaping the intellectual conditions for the rise of neo-liberal thought and the subsequent deregulation of the financial markets (Vogl, 2010), and did not foresee the depth and extent of the current crisis. We agree that a proper understanding of financial markets is fundamental to address the crisis head on. However, we see no need to wait for 'new economic thinking' to occur before an informed reflection of civil society's options to confront the root causes of the crisis may take place. We rather think that the time has come for political science and sociology to contribute towards understanding how global finance can be re-contained. In a sense, the crisis can be seen as a remarkable opportunity for all social sciences to make sense of the current predicament in both empirical and theoretical terms (Munir, 2011). This is why we will attempt to provide an overall conceptual framework loosely based on institutional theory in the concluding essay of this collection. Not only does institutional theory provide us with considerable explanatory leverage over the events related to the crisis, but it also points to hitherto unexplored options for action. At the same time, however, due to a long-standing abstinence regarding issues related to civil society's role in capitalist democracies and a tendency of institutional theory to shy away from power issues, there is some way to go in order to regain ground in empirical as well as theoretical respects. The collection of essays presented here is supposed to be one of (hopefully) many future steps in this direction.

\section{What Is Civil Society?}

Of course, civil society is not a monolith. It is populated by a universe of actors, with potentially contrasting agendas and irreconcilable interests (Fioramonti, 2007; Heinrich \& Fioramonti, 2007; Fioramonti \& Fiori 2010). In order to account for the diversity of real-life civil society - as opposed to more narrow and often romanticized understandings available in the literature (e.g. Adloff, 2005) - we have adopted the following definition: Civil society is an open arena of participation, located beyond the fuzzy boundaries of state and market, in which different types of individuals, groups and organizations cooperate or compete for visibility and relevance, in the pursuit of collective (though not necessarily shared) political and social goals and animated by a variety of values and interests. Self-organized citizens, social movements, NGOs, business associations and labour unions, loose (online) networks, philanthropic foundations and a myriad of other manifestations of public participation are all components of the civil society arena. This wide definition allows for a comprehensive and inclusive analysis of civic mobilizations, thus avoiding a common problem of normative definitions of civil society that move from preconceived notions (e.g. the inherent civility of civil society) to foregone conclusions (e.g. that civil society is a force for good). Some forces within the civil society arena are more radical than others. Some pursue their objectives through a reformist approach, while others do not refrain from entering the terrain of violence. Some engage with political and economic power, others reject it (Desai \& Said, 2001). In line with this conceptual framework, the second part of this collection presents a number of case 
studies characterized by a significant diversity in terms of degree of radicalism and cultures of engagement.

\section{What Role for Civil Society? The Case of Philanthropic Foundations}

It may be argued that change may originate from the apex of the civil society arena, through the leadership of those civic actors equipped with the intellectual, human and financial resources to make a difference. In this vein, it has been maintained that foundations are particularly promising candidates when it comes to the possibility of establishing a strong civil society infrastructure capable of reining in financial actors (Anheier, 2010a; 2010b; 2012, pp. 436-437). As mainstream social actors in the civil society arena, they would be well suited to promote some form of gradual evolutionary change in the financial world, mainly by harnessing their innovation capacity and their links with other powerful actors. While they do not play an outstandingly active role today, they might become crucially important sources of civil society support in the future as they are 'uniquely qualified to enable innovation, take social risks, and serve as philanthropic venture capital' (Anheier, 2005, p. 317). Along these lines, the very strength of foundations is to be found in their alleged independence from political and market constraints alike.

Moreover, the innovative function seems to be of high importance for the selfperception of foundations. Empirical research has indeed found that the majority of foundations see themselves as social innovators (Anheier \& Daly, 2007). As asset-based organizations that rely on a stable flow of revenues, foundations might have a comprehensible self-interest in a highly stable financial system. They have been affected by the crisis themselves since the value of their assets has dropped while demand for philanthropic support has risen. Just like many investors and businesses, even some foundations were lured into highrisk investments and faced fraudulent deals. Notorious is the case of the JEHT Foundation, which lost the bulk of its endowment through Bernard Madoff's 'Ponzi scheme' and was forced to close down in 2009. Finally, foundations' financial resources and their familiarity with issues within the private sector may easily turn them into powerful actors, should they intend to actively promote change in the financial sector. Most probably, they would also be able to harness the necessary expertise and support knowledge-based advocacy. Furthermore, some grant-making foundations have a long history of political involvement, also supporting grassroots social movements, pro-democracy groups and human rights defenders across the globe (e.g., among others, the Ford Foundation, Barrow Cadbury Trust and Joseph Rowntree Charitable Trust).

A survey we conducted in 2011 among foundations across Europe and North America identified a number of examples of progressive and cutting-edge work done with philanthropic support or by foundations themselves. However, only a minority of the respondents was actually engaging with issues related to global finance: most foundations refrained from becoming active at all (Fioramonti \& Thümler, 2011). While the mere existence of innovative examples of foundations' work shows that claims of excessive complexity and hyper-technical expertise raised to explain abstinence in this field are not entirely justified, only a minority of foundations seemed to reveal the very characteristics of innovation and autonomy generally attributed to the whole sector.

Our analysis pointed to a number of reasons why most philanthropic foundations might find it difficult to support civil society in addressing the root causes of the financial crisis. First of all, there is a path dependency effect: foundations, like most charitable organizations, have programmatic areas and funding streams that cannot be easily re-directed. In this regard, it is easier for an individual philanthropist (such as a billionaire like George Soros) to adapt to new challenges than for traditional foundations, whose decisions are often 
subject to lengthy processes of consultation. The second reason is more technical in nature. While philanthropic foundations have gathered significant knowledge with respect to social welfare issues, they have only very limited understanding of financial matters and, therefore, refrain from getting involved in a field in which they would not be able to distinguish the quality and credibility of funding proposals. Finally, there are some more political interests at play (Fioramonti \& Thümler, 2011). Many foundations have been traditionally connected with the financial sector, given that some of the most illustrious philanthropists and private donors are indeed investors and bankers. It is not unusual to find financiers sitting on the boards of directors of the most prestigious private foundations. For some of these organizations, shying away from calling the overall functioning of financial markets into question may be a convenient strategy to avoid raising conflicts of interest. Moreover, the pervasiveness of contemporary finance has been influencing also those foundations that do not have direct links with the financial world. They are indeed likely to invest their assets into high-return investment funds, which are often managed by the very same financial actors that would need reforming.

Against the backdrop of a predominant inaction by philanthropic actors we conclude that foundations are actually bounded innovators. While, at least in principle, many of them are equipped with the potential for creative innovation, they are at the same time subjected to substantial structural constraints. Hence, while foundations can be seen as relevant stakeholders in the field, it is unlikely that they will play a major role in the future course of events.

\section{From the Bottom Up?}

The prevailing literature in the relationship between civil society and financial governance focuses on the capacity of the former to engage international financial institutions such as the International Monetary Fund (IMF), the World Bank and the World Trade Organization (Nelson, 1995; O’Brien et al., 1996; Fox \& Brown, 1998). In general terms, the relationship between civil society and global finance was explored systematically for the first time in a volume edited by Scholte and Schnabel (2002). In their research, they analysed the multiple ways in which global civil society actors attempt to influence economic and financial governance. More recently, Scholte (2011) and colleagues expanded the analysis to other multilateral forums, with a view to asking whether citizens have improved the accountability of global bodies that deal with challenges such as climate change, financial crises, conflict, disease and inequality. Moreover, they asked what circumstances have promoted (or blocked) civil society efforts to make global governance institutions more democratically accountable. Finally, a special section of the Journal of Civil Society, featuring two essays by John Clark in 2011 (see Clark, 2011a; 2011b), explored the impact of major societal developments such as the financial crisis, trans-national terrorism and climate change on civil society. The contributors addressed the question of how challenges might be turned into opportunities, i.e. what an effective response by civil society actors in times of crises might look like and what overall role civil society was supposed to play.

While highly valuable as a starting point of inquiry, these accounts do not suffice for a number of reasons. First, they do not cover the whole spectrum of civil society's attempts to confront global finance. They focus strongly on the interaction between NGOs and the Bretton Woods institutions (IMF and World Bank) thus neglecting the much larger and much more powerful system of private finance - not due to a blind spot of research but as a reflection of what NGOs actually do. While not explicitly disregarding the role of social movements demonstrating outside (and against) the global governance system of conference rooms, existing scholarship has traditionally placed more emphasis on those NGOs and civic 
associations engaging with global governance structures (but see Desai \& Said, 2001 for a comprehensive discussion of civil society activism vis-à-vis global capitalism).

Second, the numerous ramifications of the current crisis reveal that the financial sector is largely unchecked, both by government and civil society. Unlike other areas within society such as environmental governance, human rights, social welfare and corporate accountability, financial markets thrive thanks to a strikingly limited regulatory power of governments and an absence of civil society actors, perhaps with the only exception of specific business associations (Orr, 2002; Scholte \& Schnabel, 2002; Anheier, 2012). According to the National Center of Charitable Statistics in the U.S., only 160 out of approximately 370,000 larger NGOs focus on public finances, taxation and policies of financial markets, equalling $0.1 \%$ of all NGOs and $1 \%$ of their overall budgets (Anheier, 2012, p. 430). In Western Europe this is also the case, with only a minor fraction of all the organizations registered at the Union of International Associations based in Brussels (Anheier, 2010a).

Third, whereas civil society is particularly weak, the very opposite is true of global finance. For instance, according to Scholte's essay in this collection, 'commercial financial transactions dwarf gross world product (of 'real' goods and services) at somewhere around US\$ 77 trillion in 2011'. As a consequence, the financial industry is endowed with an extraordinarily high degree of economic power and political influence (Streeck, 2011; 2012a). Moreover, it is backed by a powerful neoliberal ideology that has been characterized as a 'political project concerned with institutional changes on a scale not seen since the immediate aftermath of the Second World War and a project that has attempted to transform some of the most basic political and economic settlements of the post-war era' (Campbell \& Pedersen, 2001, p. 1). Confronted with this situation, the assumption that more instrumental attempts of civil society actors to enhance governance mechanisms alone might make a critical difference, or even be welcomed by financial actors as an opportunity for self-regulation (Anheier, 2012, p. 425), seems to be rather unwarranted.

Hence, we conclude that scholarly inquiry would be well advised to open the window more widely in order to capture more relevant actors as well as the more political and even the cultural preconditions of the crisis. Our approach is therefore to 1) present different ways to 'frame' the crisis and 2) identify the respective civil society's responses depending on the diagnosis in order to 3) arrive at a more encompassing, theoretically informed understanding of the character of the crisis and options for action. In the course of our own work on the role of philanthropic foundations vis-à-vis the financial crisis (Fioramonti \& Thümler, 2011) we have identified at least three different ways to think about the crisis and corresponding approaches to tackle it.

The first perspective, introduced above, focuses on the (in-)adequacy of existing governance structures. It takes as its point of departure the diagnosis, that global finance has transgressed the traditional, i.e., national, boundaries and regulations, and thus operates in an 'institutional void' (Anheier, 2012, p. 425), that is, beyond societal accountability. Similar to the state, so the argument goes, civil society has neither reached the critical mass nor found adequate ways to effectively influence the behaviour of global finance. What is necessary, then, is a stronger and more adequate civic presence and engagement in order to fill the void in sometimes contentious, but ultimately collaborative and constructive, ways with the intention to arrive at better governance structures and more effective rules of conduct. In other words, the proposed remedy consists in the development of the organizational infrastructure necessary to re-enforce accountability and to establish the arrangements necessary for rational conflict management (Anheier, 2012). For instance, civil society may act as a watchdog against unaccountable financial power much in the sense of a 'Greenpeace of financial markets' (Anheier, 2012, p. 437). Hence, the first position can also be characterized as reformist or functionalist. 
The second perspective is more explicitly political. In this view, what we observe today is a broader crisis of western political economy caused by the internal contradictions of capitalist democracies - further exacerbated by decades of neo-liberal discourse - to the effect that economic elites have achieved societal hegemony and built an ideological Weltanschaung that cannot be affected by mere regulation at all, thus possibly marginalizing democratic politics for decades to come (Streeck, 2011). Taking this diagnosis seriously, civil society can alter the behaviour of markets only under the condition that it acknowledges the inherently political and ideological nature of the conflict. This would mean that it puts power issues on the agenda, articulates indignation and wages protest and boycotts in order to challenge the prevailing power structures and to exert public pressure in the political arena in order to work towards a reinvigoration of democracy (Streeck, 2012a, pp. 786-787). It would mean to develop new societal consensus of what counts as responsible corporate citizenship and investment, in other words, to reshape societal conceptions of what kind of economic behaviour should be regarded as acceptable, and which to blame as 'impure', that is, not worthy to be protected and supported by society (Alexander, 2006, pp. 54-62; cf. also the related discussion by Kern and Nam in this collection on the duality of the civil sphere and negative values as a source of 'pollution'). According to this rather revolutionary line of argument, civil society would have to challenge not only the power of global and domestic finance but possibly the very model of capitalist democracy dominant in contemporary western societies.

Finally, the events may be interpreted in even more fundamental and systemic terms, as a basic challenge to the prevailing economic model based on continuous growth and increasing consumption (an aspect that actually transcends the traditional division between capitalism and socialism). In this perspective, the events can become an opportunity for civil society to rethink the current economic system that is untenable in the long run anyhow, as it inevitably will destroy the natural and social resources necessary for its operation. This position calls for the identification and/or development of new and more sustainable lifestyles and alternative theories of systemic (that is, human and ecological) well-being (Heinberg, 2011; Fioramonti, 2013). Under these conditions, civil society may become a locus of fundamental cultural and social change, in which the current mainstream economic model based on continuous growth is contested, and new social arrangements and ways of life are explored experimentally.

\section{Outline of this collection}

Obviously, depending on what angle one chooses to look at the crisis, there are different (albeit perhaps complementary) options for civil society actors. Accordingly, this collection reflects the multidimensional character of the current crisis by being structured along the three different levels of analysis.

In the first essay titled 'Civil Society and Financial Markets. What Is Not Happening and Why', Jan Aart Scholte has conducted an analysis of civil society's engagement with the financial world over the past 30 years. He finds that, while civil society has generally addressed public financial institutions (such as the International Monetary Fund and the World Bank), it has grossly missed the powerful and giant sector of private finance. In his words, civil society has been 'barking at a few trees while the forest is left undisturbed'. According to Scholte's analysis, there are both actor-based and structural factors explaining the lack of civil society focus on financial powers. These include limited information and knowledge of the sometimes highly complicated issues of financial products and financial markets; narrow conceptions of global financial governance (mostly limited to a few intergovernmental organisations, largely overlooking important transgovernmental networks 
and substantial private regulatory mechanisms); the intangible, invisible, seemingly remote character of finance relative to humanitarian crises, environmental damage and human rights violations; limited resources; and the structural power of finance capital, which inhibits bottom-up change at all levels, further strengthened by the dominance of the neoliberal paradigm throughout society.

Building on Scholte's diagnosis, Greg Ford and Thierry Philipponat begin their contribution on 'The Role of Civil Society in Holding Financial Powers Accountable' by looking at what 'financial power' consists of and how it has been exercised in recent years. The essay then analyses how civil society has been able to participate in the framework of the existing accountability mechanisms. They conclude that civil society is involved mostly passively as a political audience, or occasionally in a consultation, and raise doubts regarding the question of how successful and effective these roles can be. The essay then looks at the specific case of Finance Watch as a response to a request by policymakers for civil society to organize itself and start lobbying on public interest matters as a counter-weight to the financial industry.

Then the analysis shifts to the political level, namely the relationship between (neoliberal) cultural hegemony, financial power and democratic governance. Mario Pianta's contribution 'Democracy Lost: The Financial Crisis in Europe and the Role of Civil Society' discusses the crisis in the context of a wider perspective on European political economy. He claims that neoliberal reforms throughout the 1980s and 1990s made European governments vulnerable to external shocks caused by financial markets. What is more, since the early 1990s, the process of regional integration led by the European Union (EU) limited the power of national parliaments and policy makers. As a result, many European countries have come under severe pressure not only from global finance - which rates and finances sovereign debt - but also from supranational EU authorities, to the effect that national elections are distorted and national leaders are forced to bend to actual or alleged market demands. At the same time, Pianta maintains, a gulf has been growing between traditional forces within civil society (such as trade unions, NGOs, and the left-leaning intelligentsia) and a new generations of activists (such as the indignados and the Occupy movement), which do not necessarily share the view that politics - with all its necessary mediations - is the space for achieving change. While a progressive convergence among mobilisations can be identified for specific sectoral reforms, there seems to be no convergence on the means to reclaim democracy.

Taking the cue from Pianta's argument that the financial crisis reveals the weakness of democracy in the age of neo-liberalism, Thomas Kern and Sang-Hui Nam take a closer look at the Occupy Wall Street movement ("From "Corruption" to "Democracy": Cultural Values, Mobilization and the Collective Identity of the Occupy Movement'). Based on social movement theory and the considerations of Jeffrey Alexander on the civil sphere, they investigate how values and ideas have helped shape the collective identity as well as the political message of the Occupy movement. Applying the method of content analysis, they investigated publications issued by the Canadian Adbusters Media Foundation, the very organization that played a crucial role in initiating and orchestrating the Occupy movement. Based on this analysis, they conclude that the movement's collective identity was mainly shaped by the value of 'democracy', while their opponents were labelled as 'corrupt' and 'greedy' - actually quite successfully, the authors assert. In their view, Occupy established the financial and economic crisis as a target of popular mobilization, considerably shaped the perception of the financial crisis by politicians, experts and other stakeholders as a matter of public concern, and exerted a great influence on the problem's perception by scandalizing it as a matter of corrupt (mainly economic) elites. Their success is explained (among others) by the 'activation of emotional value commitments' that resonated well with the prevailing cultural framework of Western democracies. 
From a more holistic perspective, Tony Greenham and Josh-Ryan Collins argue that financial crises are a symptom of a fundamental mismatch between our financial and economic structures and desirable social and ecological goals. In their essay 'Reconceiving the Role of the Economy and Financial Markets', they suggest that neo-classical economic theory is ill-equipped to solve this mismatch, because it lacks the conceptual frameworks to even diagnose it correctly. The dominant economic thinking supports the primacy of the financial system over the economy and in turn the primacy of the economy over social needs and ecological realities. Greenham and Collins examine how financial wealth is produced and argue that, if contemporary societies are to resolve the multidimensional crisis they are facing, it is necessary to rethink the unsustainable imperative of endless economic growth. Their contribution highlights the nature of money creation by means of credit expansion as a cause of instability, and a driver of ecological and social harm. In their words, nothing less than a fundamental redesign of financial and economic systems is required. In this regard, civil society can act as a bottom-up innovator by reframing the role of the economy in relation to nature and society: markets must serve citizens and the planet, rather than the other way around.

Finally, Giacomo D'Alisa, Federico Demaria and Claudio Cattaneo present a case study in support of Greenham and Collins' view that the financial crisis is revealing a system mismatch between the goals of our economic systems and the demands of the social and ecological spheres. They analyse the phenomenon of 'degrowth' as an interpretative framework of various manifestations of civil society activism, some 'uncivil', that is, more radical (and often illegal), and some more civil and pragmatic, which share a common critique of economic growth as the guiding principle of contemporary societies. Radical strategies are explicitly discarding the growth imaginary - and therefore the entire modern way of life opening up the space for alternative socio-environmental politics. More 'civil' forms of activism hold the potential to involve a wider variety of individuals (regardless of their political views) and thus to build a strong network of pragmatic, local, day-to-day change, though they risk cooptation by market forces. Their essay discusses the origins, evolution, practices and contested construction of degrowth in France, Italy and Spain. It presents the main intellectual sources, and it shows the variety of strategies concerning oppositional activism, building of alternatives and political proposals. It also examines the movement's actors: practitioners, activists and scientists. Yet, the movement's diversity, so the authors conclude, does not detract from the existence of a common thrust and purpose.

\section{Acknowledgements}

The ideas behind this volume originated from research activities conducted in 2011 and 2012, when the Centre for Social Investment of Heidelberg University hosted Lorenzo Fioramonti as senior fellow. The fellowship, a preparatory workshop organized by the editors in December 2012 and the publication of this book were made possible by the generous funding of the Compagnia di San Paolo. We also wish to thank Volker Then and Georg Mildenberger for their persistent support and advice. Special thanks to Radost Natcheva for her research assistance.

\section{References}

Adloff, F. (2005): Zivilgesellschaft. Theorie und politische Praxis (Frankfurt/Main, New York: Campus).

Alexander, J. C. (2006) The Civil Sphere (Oxford: Oxford University Press). 
Anheier, H. K. (2005) Nonprofit Organizations. Theory, management, policy (London and New York: Routledge).

Anheier, H. K. (2010a) Neue Wächter für die Banken, DIE ZEIT, $4^{\text {th }}$ March 2010.

Anheier, H. K. (2010b) Die Zivilgesellschaft ist gefordert, The European, $14^{\text {th }}$ May 2010.

Anheier, H. K. (2012) Zivilgesellschaft und Krisen: Dahrendorf'sche Reflektionen, Leviathan, 40(3), pp. 421-440.

Anheier, H. K. \& Daly, S. (2007) Comparing Foundation Roles, in: H.K. Anheier \& S. Daly (Eds.) The Politics of Foundations. A Comparative Analysis, pp. 27-44 (London and New York: Routledge).

Campbell, J. L. \& Pedersen, O. K. (Eds.) (2001) The rise of neoliberalism and institutional analysis (Princeton, NJ: Princeton University Press).

Clark, J. (2011a) Civil Society in the Age of Crisis, Journal of Civil Society, 7(3), pp. 241263.

Clark, J. (2011b) Crisis Continues, but New Opportunities Open: A Rejoinder, Journal of Civil Society, 7(3), pp. 297-304.

Davis, G.F. (2010) After the Ownership Society: Another World is Possible, in M. Lounsbury \& P.M Hirsch (Eds.) Markets on Trial. The Economic Sociology of the US Financial Crisis, pp. 633-658 (Bingley: Emerald).

Desai, M. \& Said, Y. (2001) The New Anti-Capitalist Movement: Money and Global Civil Society, in: H. K. Anheier, M. Glasius \& M. Kaldor (Eds.) Global Civil Society 2001, pp. 51-78 (Oxford: Oxford University Press).

Fioramonti, L. (2007) The Internal Contradictions of Global Civil Society: What Impact on Democracy? Development Dialogue, (49), pp 131-141.

Fioramonti, L. \& Fiori, A. (2010) Civil Society After Democracy: The Evolution of Civic Activism in South Africa and Korea, Journal of Civil Society, 6 (1), pp 23-38.

Fioramonti, L. \& Thümler, E. (2011) The Financial Crisis and the Nonprofit Sector: Can Philanthropic Foundations Support the Creation of a Civic Watchdog of International Finance? The International Journal of Not-For-Profit Law, 13(3), pp. 3342.

Fox, J. A. \& Brown, L. D. (Eds.) (1998) The Struggle for Accountability: The World Bank, Ngos, and Grassroots Movements (Cambridge, MA: MIT Press).

Gramsci, A. (1971) Selections from the Prison Notebooks of Antonio Gramsci (New York: International Publishers).

Habermas, J. (2011) Rettet die Würde der Demokratie, Frankfurter Allgemeine Zeitung, $4^{\text {th }}$ November 2011.

Heinberg, R. (2011) The End of Growth. Adapting to Our New Economic Reality (Gabriola Island, BC: New Society Publishers).

Heinrich, V.F. \& Fioramonti, L. (2007) Global Survey of the State of Civil Society: Comparative Perspectives (Bloomfield: Kumarian Press).

Lounsbury, M. \& Hirsch, P.M. (Eds.) (2010) Markets on Trial. The Economic Sociology of the US Financial Crisis (Bingley: Emerald).

Minhas, S. \& Buteau, E. (2010) A Time of Need: Nonprofits Report Poor Communication and Little Help from Foundations During the Economic Downturn (Cambridge, MA and San Francisco: The Center for Effective Philanthropy).

Munir, K. A. (2011) Financial Crisis 2008-2009: What Does the Silence of Institutional Theorists Tell Us? Journal of Management Inquiry, 20(2), pp. 114-117.

Nelson, P. J. (Ed.) (1995) The World Bank and non-governmental organizations. The limits of apolitical development (London: Macmillan).

O'Brien, R., Goetz, A. M., Scholte, J. A. \& Williams, M. (Eds.) (1996) Contesting Global Governance: Multilateral Economic Institutions and Global Social Movements (Cambridge: Cambridge University Press). 
Orr, J. C. (2002) Business associations and global financial governance, in: J. A. Scholte (Ed.) Civil society and global finance, pp. 199-212 (London: Routledge).

Roubini, N. \& Mihm, S. (2011) Crisis Economics: A Crash Course in the Future of Finance (New York: Penguin Books).

Scholte, J. A. \& Schnabel, A. (Eds.) (2002) Civil Society and Global Finance (London: Routledge).

Scholte, J. A. (Ed.) (2011) Building Global Democracy? Civil Society and Accountable Global Governance (Cambridge: Cambridge University Press).

Sen, A. (2009) Capitalism Beyond the Crisis, The New York Review of Books, March $26^{\text {th }} 2009$.

Stiglitz, J. (2010) Freefall: Free Markets and the Sinking of the World Economy (New York: W.W. Norton \& Co.)

Stiglitz, J. (2012) The Price of Inequality (New York and London: Norton).

Streeck, W. (2011) A crisis of democratic capitalism, New Left Review, 71, pp. 1-25.

Streeck, W. (2012a) Wissen als Macht, Macht als Wissen. Kapitalversteher im

Krisenkapitalismus, Merkur, (9/10), pp. 776-787.

Streeck, W. (2012b) Der öffentliche Auftrag der Soziologie, Leviathan, 40(1), pp. 129-147.

Vogl, J. (2010) Das Gespenst des Kapitals (Zürich: Diaphanes). 